\title{
Designing hotspots in the public spaces and public greenery of modern cities - selected issues
}

\author{
Marzena Suchocka*, Kinga Kimic, Magdalena Błaszczyk, Natalia Kołodyńska \\ Department of Landscape Architecture, Institute of Environmental Engineering, \\ Warsaw University of Life Sciences Nowoursynowska Street 159, 02-776 Warsaw, Poland \\ *e-mail: marzena.suchocka@interia.pl \\ Received: 27 July 2019 / Accepted: 12 October 2019
}

\begin{abstract}
The idea of smart cities is no longer just a vision of urban planners, authorities, and ordinary people - it is being implemented to an ever broader extent. Activities aimed at the accomplishment of the goals set for contemporary cities, oriented at making them "smart", involve numerous areas, including public and green spaces. In order to increase the attractiveness of these areas and to encourage potential users to make use of them to an increasingly greater extent, it is recommended to make it possible for them to easily use wireless networks in public and green spaces, while at the same time working on the principles of organising the surroundings of the hotspots, increasing the comfort of their use. What is key in this respect is not only to adjust the parameters of the basic features of the Wi-Fi signal, but also to take into consideration the spatial elements, such as the landform features and plant coverage. An analysis of the above-mentioned factors related to the use of Wi-Fi in the open air made it possible to formulate recommendations for shaping the hotspot space in these places. They apply to public spaces, including in particular green spaces in cities, as in these places, there is real demand for outdoor wireless Internet access.
\end{abstract}

Key words: hotspot; Internet; green space; public space; smart city; wireless network.

\section{Introduction}

Nowadays, social needs and expectations related to access to information via the Internet, oriented at making use of it at any time and place, are changing. The development of contemporary society is part of the megatrends we have been able to observe for several decades now, including departure from the industrial society in favour of the information society (IS) (Naisbitt, 1992; Stacewicz, 1998). This means mass use of information and communication technologies (ICT) (Lubacz \& Galar, 1999) - increasingly broader access to online information, along with the expansion of mobile devices and services (Tinnilä, 2012) and collecting more and more data, including growing consumerism and further urbanisation (Dobbs et al., 2015).

The information society, for which knowledge and information constitute the basis of existence (Krzysztofek
\& Szczepański, 2005), includes various generations. Above all, "digital natives", i.e. people born in the digital era, for whom the new media are the basic environment in which they function. Thanks to innovative mobile devices, they have direct and permanent access to these media (Prensky, 2001; Mensch, 2009), and the use of information via the Internet is a parallel and multi-layered process ${ }^{1}$. The Internet may become an addictive factor, as without permanent access to the network, representatives of this group may feel lost or have a sense of fear of missing out on

\footnotetext{
1 This is defined as media convergence or device convergence. Mysior, R. (2016). Dwa światy - cyfrowi tubylcy, cyfrowi imigranci - cz. I. Available at: http://www.remedium-psychologia. p1/2014_09_3.pdf; s. 1-2 [Accessed 12 March 2016].
} 
something ${ }^{2}$ (Przybylski et al., 2013). Also the older representatives of society, called "digital immigrants", increasingly participate in the process of internalisation, using innovative information and communication technologies to a lower extent, but also in many ways (Prensky, 2001). An increase in the popularity of mobile devices and the constantly decreasing costs of data transfer are the reason that currently, a considerable part of society remains online at all times. Due to these changes, unfavourable changes in leisure patterns can be observed among the representatives of the information society fascinated by technology, overcome by physical laziness, isolation from nature, and staying in enclosed spaces - they spend less and less time in the open air and appreciate the value of greenery for their comfort of life (Kimic et al., 2016, 2019; Suchocka et al., 2017a; Suchocka et al., 2019a,b,c).

A growing number of hotspots in the open air shows how important their presence in the public and green spaces is to the inhabitants, which is confirmed, among others, by projects initiated by communities and municipal authorities as part of participatory budgeting in more and more Polish cities (Warsaw, Lublin, Łódź, Kielce, Kraków, Wrocław, and others) (Gdak, 2013). The significance of the Internet as an important factor encouraging leisure in the open air is also confirmed by international studies, including some from the USA, in which $75 \%$ of respondents admitted that having two places with similar facilities and a similar offering to choose from, they will go for those in which wireless Internet is available (Forlando, 2008). Positive attitude towards new technologies is demonstrated by over a half of the Poles, which gives us reason to believe that the development of these areas of life will be even more desirable in the coming years (CBOS, 2018).

\section{Objectives and methods}

The development of technology forces the introduction of new solutions in the shaping of public spaces, including green spaces. The aim of the publication is to present the selected, and at the same time most important elements making up a hotspot in terms of shaping its space, which determine its attractiveness and should be introduced at the stage of designing open access points outdoors. The research involved an analysis of the determinants and elements important to mobile Internet users. The guidelines apply to a set of information concerning not only the basic parameters of the technical elements, but also designing the immediate surroundings of hotspots with reference to

\footnotetext{
2 FOMO (Fear of Missing Out) - in Internet and social media users, it means an apprehension that they might completely miss out on something, e.g. an opportunity, interaction or experience.
}

landform features and plant coverage. These elements constitute a group of leading mobile devices effectively supporting the process of encouraging users to use the Internet in the open air, increasing the attractiveness and improving the functioning of public spaces, including green spaces. Simultaneous development of technologies and the principles of shaping public spaces with the benefits resulting from the introduction of plants is possible and not mutually exclusive.

\section{The Internet in Poland and its users}

The first analogue Internet connection in Poland was launched on 26 September 1990. It was the moment the Internet network began to develop. A rapid increase in the number of users occurred in the previous decade. In 2002, just under one fifth of the Poles $(17 \%)$ were using the Internet, while towards the end of that period, in 2010, more than a half $(51 \%)$ declared their use of the medium. Currently, Internet users constitute about $64 \%$ of people aged above 15 and more than $75 \%$ of the Poles have easy access to the Internet. The main declared reason for not using it is the lack of competence, not the lack of opportunity (CBOS, 2018). Over $88 \%$ of users connect to the Internet wirelessly, but it is hard to call them mobile users, as they connect mainly at home and at work via their own private network using a router. Only $23 \%$ of Internet users use data transmission on their mobile devices or public access points (Batorski, 2013a). The average cost of mobile Internet (actual monthly cost of the transfer of 1GB of data) for an individual customer is PLN 66.75, while for a business customer, it is lower by PLN 5.79 (PLN 60.96). The cost is expected to decrease slightly over the years (UKE, 2013). However, the financial, as well as the technological aspects are losing significance, as virtually every Pole owns a device enabling connection to the Internet (Batorski, 2013). The most popular devices used by mobile users include laptops, mobile phones, smartphones, and tablets. The use of a wireless connection does not exclude the use of a wireless network by the same user (multiscreening and multitasking) (CBOS, 2018).

It is estimated that the development and use of the mobile Internet is delayed by 4 to 8 years compared to the traditional Internet (Batorski, 2013). However, research shows that mobile access will function as an alternative to the traditional connection and not - as it has been to date only complement it. The devices used most often to connect to the mobile Internet are smartphones (CBOS, 2018).

The main factor determining the accessibility of the Internet is age. The majority of the users are young people aged 18-24 (100\%), but respondents aged 25-34 demonstrate similar activity (96\%) (CBOS, 2018). The Internet is a natural environment for young people who have digital 
competence, regardless of their economic status or education. Currently, already over $95 \%$ of pre-school children have access to the Internet. For the future generations, web access at any place will be something obvious.

Another important factor is the level of education. The largest group of Internet users are students (99\% of school pupils and students) and people with a higher education degree $(92 \%)$ or secondary education $(76 \%)$. In the group of people with basic vocational education, $52 \%$ of respondents are Internet users. The smallest percentage of Internet users can be found in the group of people with primary education, and this applies largely to people aged over 30 (CBOS, 2018).

Internet users spend an average of 13 hours a week online. Since 2009, the average declared time of using the Internet has remained at a fairly similar level. The number of hours spent online is related to age. People aged below 25 spend nearly twice as much time weekly using the Internet (about $23.8 \mathrm{~h}$ ) than older users $(7.59 \mathrm{~h}$ on average) (CBOS, 2018).

At the initial stages of Internet development, it was used mainly at home and at work. Along with the increase in the popularity of the wireless Internet, the term "third place revolution" appeared, which describes the growing number of log-ins in places different than home and work. The "third places" where we use the Internet are most often cafés, restaurants, and hotels. In this revolution, parks currently only play a small part, as the number of public spaces offering wireless access to the Internet is small compared to commercial venues (Park, 2010). Apart from the lack of telecommunications infrastructure, an additional impediment in this case is the lack of convenience in using mobile devices, which was emphasised by users in the surveys carried out (Suchocka et al., 2017b). At the same time, the place where the Poles use the Internet most often is their homes ( $97 \%$ of respondents). Only $2 \%$ connect to the web in Internet cafés.

The collected information shows that Internet users are not a homogenous group, but certain behaviours are common and make it possible to create the profiles of typical Internet users.

\section{Internet users in the public space}

The time spent in front of the screens of mobile devices is found mainly at the expense of activity in the open air. The Poles' deteriorating physical condition is largely due to more time spent in the sitting position. Increasing the frequency of people choosing to spend their time outdoors and expanding the range of places enabling work, studying or leisure in the open air would therefore be a chance to improve the physical and mental health of Internet users. Busy people need a stimulus to take up an activity. Surely, for health and social reasons, it will be a better solution than using the Internet in enclosed spaces. Even a walk to the Wi-Fi park is in itself an additional activity and people are forced to make a physical effort different than their daily activities and to assume various body positions without being aware of it. The creation of a well-designed place enabling the use of the wireless Internet gives users a chance to work, study or entertain themselves in an unusual place and to increase the amount of time spent outdoors (Ruchinskaya et al., 2019). Moreover, this type of places enable: greater integration, making friends with various people, intensification of interpersonal relationships (Park, 2010), an increase in society's involvement (Hampton et al., 2010), an increase in the amount of stimuli, gaining and exchange of experiences, ideas, and observations (Bargh \& McKenna, 2004), drawing inspiration from the surroundings, changes in the manner of forming bonds, creating social bridges thanks to which we spend time in various environments (Hampton \& Gupta, 2008), a decrease in social inequalities and spreading access to the Internet (Gillett, 2006), finding a reason to get out of the house, change the environment, and expand one's private space; they enable people who cannot live without technology to make additional spaces familiar and increase their contact with nature (currently, the Internet is treated by some people as a virtual public space replacing their presence and relationships in the real world).

Spending time in and with the community increases people's motivation to act and the sight of other busy people motivates and inspires them. Stimulation takes place at many levels and provides a rich sensory experience. The amount of stimuli and situations is unlimited. The presence of other people is the greatest value of public spaces (Gehl, 1987). Mobile Internet users are able to focus on the activities they perform and they are not bothered by moderate noise and activity of other people (Chałdyniak, 2009).

\section{Hotspot organisation in the open air}

Hotspots are open access points making it possible to connect to the Internet via a wireless network (the operational diagram is presented in Figure 1). Wireless local area networks (WLAN) are used for hotspots. The standardised and most popular wireless network technology is Wi-Fi. Electromagnetic waves (radio or infrared waves) are the transmission medium in the connections of this type. The main, most visible element of each hotspot is the access point (AP). It is a sending/receiving device, usually a router, which enables access to a different, wired computer network, through which access to services is possible. When building hotspots, a network using the star topology is usually applied - with a central base point (AP). The information package which is sent from the network node is re- 
ceived at the central station and directed to the proper end node. Users connect to the Internet using laptops, smartphones, tablets, and other devices equipped with an 802.11 wireless LAN card (Chałdyniak, 2009). If the network is to cover an area exceeding $100 \mathrm{~m}$ (WLAN has a theoretical range of about $500 \mathrm{~m}$, but the presence of natural obstacles considerably decreases that range), then in the open air, additional access points should be installed or the AP should be supported with directional antennas, whose areas of coverage will overlap in at least 30\% (Ibidem). This will make it possible for the user to move around freely without losing signal. The devices may be powered traditionally, with batteries or with solar energy (Roos, 2011).

The connection speed also depends on the standard of the Wi-Fi network. Wireless network standards differ in terms of radio frequency $(2.4 \mathrm{GHz}, 5 \mathrm{GHz})$, signal range, and the maximum transmission speed, but they were constructed so that it is possible to move smoothly between different access points (the so-called roaming function, which automatically redirects the connection to use a better signal). Currently, the most popular and the fastest standard is the $\mathrm{N}$ standard with the largest range and much higher maximum transmission speed. Another popular standard used when creating hotspots is the G standard (802.11 g).
Depending on the hotspot administrator, the service may be provided free of charge (with temporary or unlimited access) or commercially, but also to a limited extent (e.g. access only to the website of the institution providing the Internet connection) (Stróżyńska, 2014).

\section{The technological aspect}

The Wi-Fi technology makes it possible to split the wireless signal with small financial outlays. Table 1 presents the comparison between the Wi-Fi technology and data transfer, i.e. the two technologies possible to use and widely used in the open air. The most important factors for hotspot organisation were included here.

From the technological point of view, the greatest problem is the relatively small distance over which the WiFi signal works efficiently and without interferences. The distance is about $100-300 \mathrm{~m}$ and the range depends on the equipment of the surroundings, the landform features, hardware and software, as well as the manner in which the signal is emitted. A large concentration of networks (channels and bands) in the city may cause them to overlap. Paradoxically, one of the more significant issues is the law

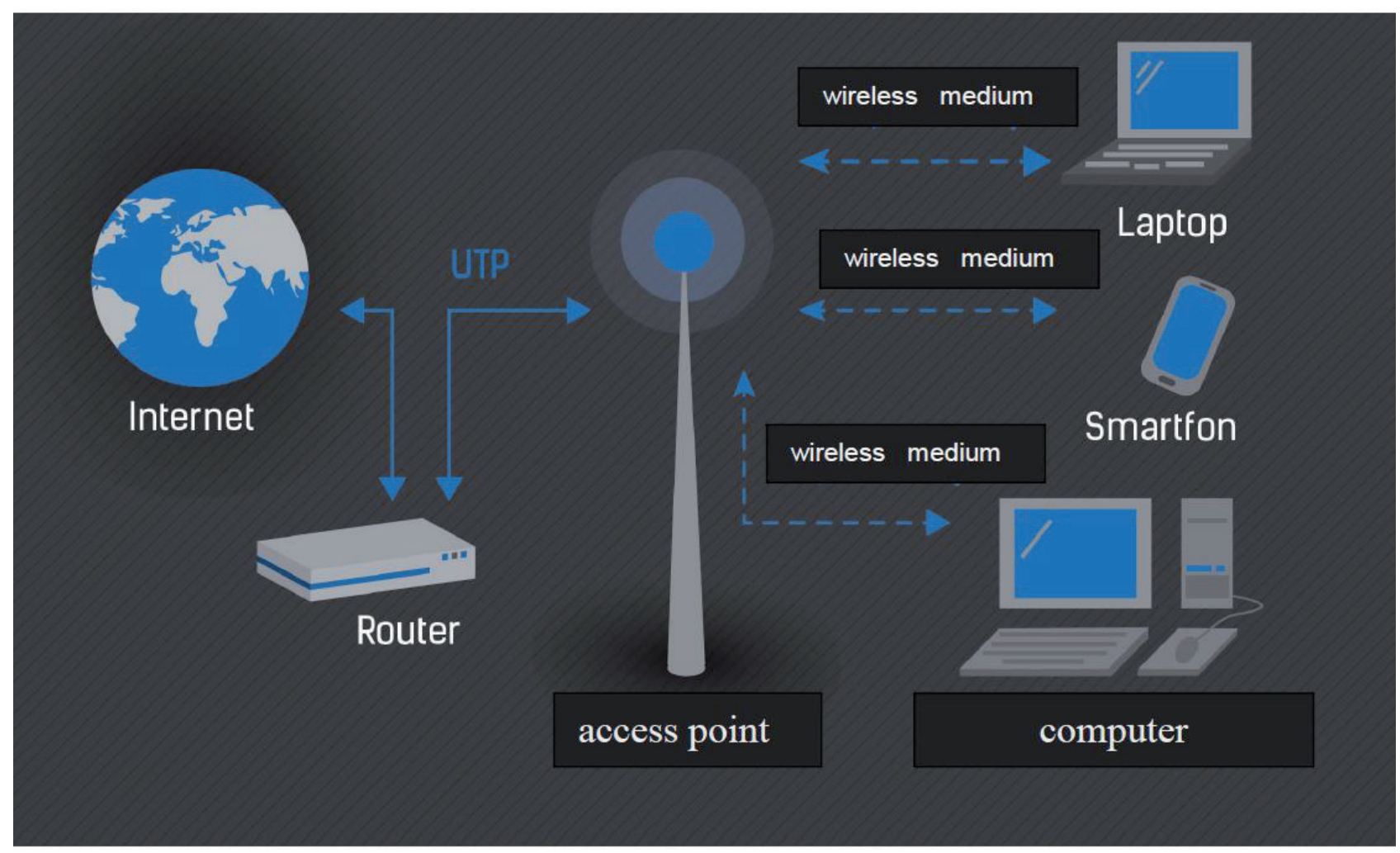

Figure 1. Operational diagram of an access point. Source: own elaboration 
imposing limits which make it impossible to efficiently support the increasingly elaborate websites and applications (Gillet, 2006). The best signal can be achieved when line-of-sight (LOS) conditions are maintained, which is difficult to achieve among high-density buildings or trees, which is why it is essential to properly plan out the presence of the factors influencing propagation. The quality and attenuation of radio waves is influenced by obstacles of considerable thickness and density (Jasiński, 2011).

\section{The influence of construction materials on the propagation of radio waves}

It is much more difficult to provide proper range in a densely built-up area than in an empty space. Buildings influence the reliability, speed, and quality of the connection to a much larger extent. Steel elements cause uncontrolled signal reflections and their paths to overlap. Walls (concrete, gypsum, etc. elements) absorb signal to a much larger extent than plants (Table 2). As a result, the device loses signal and using the wireless network is largely impeded or simply impossible. The selection of the construction materials in the surroundings of a hotspot should be sensible and influence the propagation and attenuation of the waves as little as possible. Research shows only a slight difference in the absorption of waves with the frequency of $2.4 \mathrm{GHz}$ and $5 \mathrm{GHz}$ in construction materials (Wilson, 2002). This is why the best materials to use when supplying hotspot equipment are gypsum, wooden, and glass elements.

Table 1. Comparison between a Wi-Fi connection and data transfer (advantageous features were marked in blue)

\begin{tabular}{|c|c|c|}
\hline Features & Wi-Fi connection & Data transfer \\
\hline Connection speed & $\begin{array}{l}\text { transfer speed of about } 54 \mathrm{Mbit} / \mathrm{s} \text { (within the } \\
\text { hotspot) }\end{array}$ & with the use of the telecommunications packages $30-80 \mathrm{kbps}$ \\
\hline Range & $\begin{array}{l}\text { within the range of the signal transmitter } \\
\text { (max. } 500 \mathrm{~m} \text { of theoretical range) }\end{array}$ & within the range of the telecommunications network \\
\hline Cost & $\begin{array}{l}\text { paid/free of charge (depending on the access } \\
\text { point) }\end{array}$ & paid depending on the operator's rates \\
\hline Receiving device & all the devices supporting the Wi-Fi standard & $\begin{array}{l}\text { only the devices enabling data transfer or support with the use } \\
\text { of a modem providing data transfer }\end{array}$ \\
\hline $\begin{array}{l}\text { Energy } \\
\text { consumption }\end{array}$ & $\begin{array}{l}\text { lower (due to lower energy consumption } \\
\text { when searching for the transmitter) }\end{array}$ & $\begin{array}{l}\text { higher (the device makes more frequent attempts at finding } \\
\text { the transmitter at the expense of energy consumption) }\end{array}$ \\
\hline
\end{tabular}

Source: own elaboration based on Gillet (2006).

Table 2. Radio wave attenuation by construction materials

\begin{tabular}{|c|c|c|c|}
\hline Element & Material & Material thickness [cm] & $\begin{array}{c}\text { Radio wave attenuation } \\
\text { [dB] }\end{array}$ \\
\hline Inner wall & Brick & 10 & 7 \\
\hline Outer wall & Brick & 30 & 2 \\
\hline Partition wall & Gypsum and glass wool & 7 & 11 \\
\hline Ceiling & Concrete & 2 x window panel $+1 \mathrm{~cm}$ of space & 4.5 \\
\hline Window & Glass & 4 & 2.5 \\
\hline Door & Wood & & 2 \\
\hline
\end{tabular}

Source: Jasiński (2011). 


\section{Natural elements of the surroundings determining the attractiveness of the hotspots}

Surveys have shown that when designing a hotspot, it is essential to pay particular attention to the features of the surroundings (ordered according to user preferences) such as: providing a fast and stable connection, the possibility to charge the devices, a comfortable place to work, safety, the possibility to work in peace, the best possible solutions protecting from unfavourable weather conditions, aesthetically pleasing surroundings, proximity of eating places, the place's reputation, presence of CCTV (Suchocka et al., 2017b). Answers to the question about the most undesirable factors, in accordance with the users' declarations, formed the following hierarchy of importance: lack of possibility to charge the devices, lack of a comfortable place to work, noise, reflections of sunlight on the screen, presence of large numbers of other people, presence of insects and pollens, possibility of other people seeing one's screen, unaesthetic surroundings.

\section{Landform features}

As already mentioned above, the actual range of the signal propagating from the transmitter covers an area within about a 100-metre radius. In cities, there are usually no considerable terrain irregularities. However, it is a good idea to avoid hills and considerable depressions in the terrain within the area of the planned range of the hotspot. It was proven that - on account of the comfort of use people try to walk around or avoid spaces with considerable level differences. For most people, they pose a physical or mental barrier. However, minor well-thought-out modifications to the lie of the land may arouse curiosity, add variety to the given space, and help clearly section off separate functional zones (Gehl, 1987), such as the hotspot zone. When applying changes to terrain level, it is, however, necessary to take into consideration the needs of the disabled and adjust the facilities accordingly - this applies to all the public spaces, including hotspots constituting an integral element of such places. The construction of ramps and elimination of kerbs will make it easier for people with mobility impairments to move around.

\section{The role of plants in the development of hotspots}

The surroundings of access points to the wireless Internet constitute a special type of space. Locating hotspots in green spaces (squares, parks) and their vicinity is also justified for technical reasons. The proper selection of plants may limit losses in signal strength which occur due to the presence of water in the plants and the electrically conducting ions dissolved in it, which results in the disturbances in radio wave propagation. This is why proper selection of plants for each layer is an important element when designing the hotspot space in the open air, as it will help control the propagation of radio waves and provide optimal conditions for the use of mobile devices. Not all of the plant parameters have a negative influence on signal propagation. Factors such as the size of the tree and the width of the crown have a smaller influence on the propagation of radio waves. The presence of foliage is of more significance - the size, arrangement, and shape of the leaves, as well as the number of trees between the receiver and the transmitter (Lacán \& McBride, 2009).

Apart from aesthetic and composition qualities, plants may also have other important functions contributing to the attractiveness and increasing the functionality of wireless network access points. Trees and bushes with proper height and foliage may define the boundary of signal propagation, at the same time preventing the waves from reflecting from other natural obstacles. Plants with thinner foliage may provide desirable shade and at the same time mark out the individual sub-zones of the hotspot. The proper selection of low-growing plant species may increase the comfort of spending time within the hotspot - e.g. it is a good idea to use plants scaring off bothersome insects.

For the purposes of designing Internet access points, five plant categories may be distinguished: high trees with thick foliage, high trees with thin foliage, medium-height bushes with thick foliage, medium-height bushes with thin foliage, and low-growing plants with thick foliage (Table 3 ).

\section{Summary and conclusions}

A hotspot may be a tool commonly used in green spaces as a response to the contemporary social needs related to the strong urge to have access to the Internet and information in any place. However, these places have to be attractive and provide comfort of use. The quality and attractiveness of a hotspot developed in the open air will be determined both by the technical elements of the device itself (properly configured range of the radio waves and their strength) and by the form and shape of other elements making it easier to use hotspots in a user-friendly environment and encouraging people to use them. The landform features along with the presence of plants may considerably increase the value of such places. Meeting the users' requirements, as well as the presence of the elements described in this publication is one of the bases of designing hotspots, whereas their arrangement may take on various forms, limited only by 


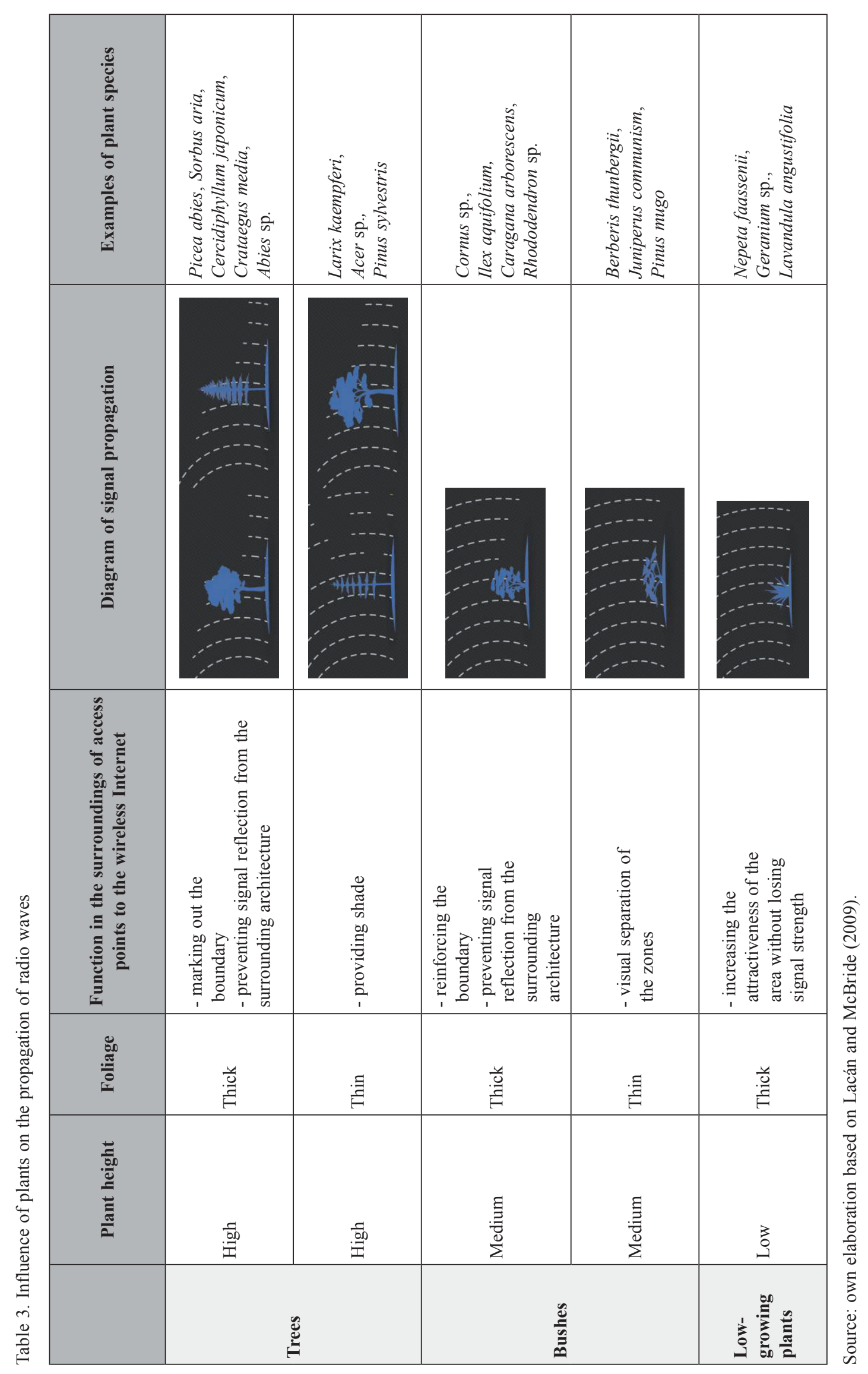


the possibilities of the available place, as well as the knowledge and vision of the designers.

\section{References}

Bargh J.A. \& McKenna K.Y.A., 2004, The Internet and Social Life, Annual Review of Psychology 55: 573-590.

Batorski D., 2013, Polacy wobec technologii cyfrowych uwarunkowania dostępności i sposobów korzystania. Diagnoza Społeczna 2013. Warunki i Jakość Życia Polaków - Raport [Poles and communication technology - access conditions and modes of use. Social Diagnosis 2013. Objective nad subjective quality of life in Poland], Contemporary Economics [Special issue] 7: 317-341.

CBOS, 2018, Korzystanie z Internetu, Komunikat z badań 6/2018 [Using the Internet. Reserach Statement], Fundacja Centrum Badania Opinii Społecznej, Warszawa. (https://www.cbos.pl/SPISKOM.POL/2017/K_049_17. PDF), [Accessed 27 March 2019].

Chaładyniak D., 2009, Podstawy działania sieci bezprzewodowych [Wireless networking basics]. Warszawska Wyższa Szkoła Informatyki, Warszawa.

Dobbs R., Manyika J. \& Woetzel J., 2015, No Ordinary Disruption. The four global forces breaking all the trends. McKinsey Report. McKinsey Global Institute.

Forlano L., 2008, Anytime? Anywhere?: Reframing Debates Around Municipal Wireless Networking. The Journal of Community Informatics 4(1): 1-23. (http:// ci-journal.net/index.php/ciej/article/view/438/401), [Accessed 10 Apr. 2016].

Gdak E., 2013, Miejski Salon [City livingroom]. Zieleń Miejska 10(78): 32-34.

Gehl J., 1987, Life Between Buildings: Using Public Space. Van Nostrand Reinhold, New York.

Gillett S.E., 2006, Municipal wireless broadband: Hype or harbinger? Southern California Law Review 79: 561-594.

Hampton K.N. \& Gupta N., 2008, Community and Social Interaction in the Wireless City: Wi-Fi use in Public and Semi- Public Spaces. New Media \& Society 10(6): 831-850.

Hampton K.N., Livio O. \& Session L., 2010, The Social Life of Wireless Urban Spaces: Internet Use, Social Networks, and the Public Realm. Journal of Communication 60(4): 701-722.

Jasiński Ł., 2011, Pomiar tłumienia ścian i innych elementów charakterystycznych dla środowiska wewnątrzbudynkowego w paśmie 2,4 GHz [Suppression of walls and other characteristic elements in the $2,4 \mathrm{GHz}$ band for the indoor environment]. Wrocław. (http://blog.alvarus.org/wp-content/uploads/2014/04/ Lukasz-Jasinski-Pomiar-tlumienia-scian-i-innych- elementow-charakterystycznych-dla-srodowiskawewnatrzbudynkowego-w-pasmie-2-4GHz.pdf), [Accessed:10 July 2014].

Kimic K., Maksymiuk G. \& Suchocka M., 2019, The application of new technologies in promoting a healthy lifestyle: selected examples. Bulletin of Geography, Socio-economic Series, 43(43): 121-130. (doi:: http:// doi.org/10.2478/bog-2019-0008).

Kimic K., Suchocka M., Maksymiuk G., Kołodyńska N., 2016. Preferencje i oczekiwania użytkowników Internetu jako podstawa kształtowania hotspotów w przestrzeniach publicznych miast [Preferences and expectations of the Intenet users as basics for hotspot designing in public spaces], [in:] D. Gałuszko, G. Ptaszek, D. Żuchowska-Skiba (eds.), Technologicznospołeczne oblicza XXI wieku [Technological and social aspects of the 21 st century]. Wydawnictwo LIBRON, Kraków: 159-182.

Krzysztofek K. \& Szczepański M., 2005, Zrozumieć rozwój. Od społeczeństw tradycyjnych do informacyjnych, Podręcznik socjologii rozwoju społecznego dla studentów socjologii, nauk politycznych i ekonomii [Understanding the development. From traditional to informational societies, Sociology of the social development for the students of sociology, political science and economics]. Wydawnictwo UŚ, Katowice.

Lacán I. \& McBride J.R., 2009, City Trees and Municipal Wi-Fi Networks: Compatibility or Conflict? Arboriculture \& Urban Forestry 35(4): 203-210.

Lubacz J.R. \& Galar R, 1999, Infrastruktura informacyjna i okolice [Informational infrastructure and the surroundings], [in:] J. Lubacz (ed.), W drodze do społeczeństwa informacyjnego [On the way to the informational society]. Wydawnictwo OWPW, Warszawa.

Mesch G.S., 2009, The Internet and Youth Culture. The Hedgehog Review 11(1): 50-60. (http://www.iascculture.org/THR/hedgehog_review_2009-Spring.php), [Accessed 8 Aug. 2014].

Mysior R., 2016, Dwa światy - cyfrowi tubylcy, cyfrowi imigranci - cz. I [Two worlds - digital natives, digital immigrants - part I]. (http://www.remedium-psychologia.pl/2014_09_3.pdf; s. 1-2), [Accessed: 12 March 2016].

Naisbitt J., 1992, Megatrends. Ten New Directions Transforming Our Lives. Warner Books, New York.

Park N., 2010, Integration of Internet Use with public spaces: College students' use of the wireless Internet and offline socializing. Cyberpsychology: Journal of Psychosocial Research on Cyberspace 4(2), article 4. (https://cyberpsychology.eu/article/view/4236/3281), [Accessed: 10 Apr. 2017].

Prensky M., 2001, Digital Natives, Digital Immigrants, On the Horizon, 9(5): 1-6. (https://doi. 
org/10.1108/10748120110424816), [Accessed 6 Apr. 2017].

Przybylski A.K., Murayama K., DeHaan C.R. \& Gladwell V., 2013, Motivational, emotional, and behavioral correlates of fear of missing out. Computers in Human Behavior, 29(4): 1841-1848.

Ruchinskaya T., Ioannidis K. \& Kimic K., 2019, Revealing the Potential of Public Places: Adding a New Digital Layer to the Existing Thematic Gardens in Thessaloniki Waterfront, [in:] C. Smaniotto Costa, I. Šuklje Erjavec, M. de Lange, K. Ioannidis, G. Maksymiuk, M. de Waal (eds.), CyberParks - The Interface Between People, Places and Technology. Springer International Publishing, Switzerland: 181-195. (doi: https://doi. org/10.1007/978-3-030-13417-4_15).

Roos D., 2011, How Wireless Mesh Networks Work. (http://computer.howstuffworks.com/how-wirelessmesh-networks-work.htm), [Accessed 13 Nov. 2014].

Stacewicz J., 1998, Polityka gospodarcza [Economic Policy], Warszawa, Oficyna Wydawnicza SGH.

Stróżyńska A., 2014, Stanowisko Prezesa UKE (dot. retencji danych) [The President of UKE opinion regarding data retention]. (https://www.uke.gov.pl/stanowisko-prezesa-uke-10964\#), [Accessed 20 Oct. 2014].

Suchocka M., Kimic K., Maksymiuk G. \& Kołodyńska N., 2017a, Outdoor hotspots as a tool for enhancing healthy lifestyles of ICT users. Design and development principles [in:] A. Zammit and Th. Kenna (eds.), Enhancing places through technology. Proceedings from the ICiTy conference Valletta, Malta - April 18-19, 2016, Series: Culture \&Territory, CyberParks Project. Edições Universitárias Lusófonas, Lisbon: 153-165.

Suchocka M., Maksymiuk G., Kimic K. \& Kołodyńska N., 2017b. Behaviour, expectations and preferences of 'digital natives' in regard to the design of urban public spaces [in:] A. Zammit, Th. Kenna (eds.), Enhancing places through technology. Proceedings from the ICiTy conference, Valletta, Malta - April 18-19, 2016, Series: Culture\&Territory, CyberParks Project. Edições Universitárias Lusófonas, Lisbon: 117-128.

Suchocka M., Jankowski P. \& Błaszczyk M., 2019a, Perception of Urban Trees by Polish Tree Professionals vs. Non-Professionals. Sustainability 11(1): 211. (doi: org/10.3390/su11010211).

Suchocka M., Jankowski P. \& Błaszczyk M., 2019b. Tree protection on construction sites - knowledge and perception of Polish professionals. Urban Forestry \& Urban Greening Vol 46, 126436. (doi: org/10.1016/j. ufug.2019.126436).

Suchocka M., Błaszczyk M., Juźwiak A., Duriasz J., Bohdan A. \& Stolarczyk J., 2019c, Transit verus Nature. Value Depreciation of Road Alleys. Case study: Gamerki-Jonkowo, Poland. Sustainability 11(6): 1816. (doi: 10.3390/su110618).

UKE, 2013, Office of Electronic Communications. (https:// uke.gov.pl/en/), [Accessed 22 Oct. 2014].

Tinnilä M., 2012, Impact of Future Trends on Banking Services, Journal of Internet Banking \& Commerce 17(2): $1-15$, Special section.

Wilson R., 2002, Propagation Losses Through Common Building Materials 2,4 GHz vs $5 \mathrm{GHz}$. Reflection and Transmission Losses Through Common Bulding Materials, Magis Network, Inc. (https://www.am1.us/ wp-content/uploads/Documents/E10589_Propagation Losses_2_and_5GHz.pdf), [Accessed 22 Oct. 2018]. 